IFN Working Paper No. 785, 2009

\title{
How Much does Sweden Invest in Intangible Assets?
}

Harald Edquist 


\title{
How Much does Sweden Invest in Intangible Assets?*
}

By

\author{
Harald Edquist ${ }^{\dagger}$
}

2008-01-26

JEL-codes: O15; O16; O47; O52

Key-words: Intangibles; Investment; Economic growth

\begin{abstract}
In this paper I attempt to replicate for Sweden the Corrado, Hulten and Sichel (2006) and Marrano and Haskel (2006) working papers on spending on intangible assets in the US and the UK. Based on their measurement methods the total spending on intangibles in Sweden in 2004 was 277 billion SEK or 10.6 percent of total GDP. Based on total spending it can be estimated that total investment in intangibles was 227 billion or approximately two-thirds of the total investment in fixed capital in 2004. Thus, investment in intangibles was considerable in 2004. The corresponding figures for the UK and the US were 10.9 and 13.1 percent, respectively. Even though the measurement methods of intangibles must be further developed, it could be argued that intangibles in the future should be included in the Swedish national accounts.
\end{abstract}

Financial support has been provided by the COINVEST project, www.coinvest.org.uk, funded by the European Commission Seventh Framework Programme, Theme 9, Socio-economic Science and Humanities, grant number 217512.

\footnotetext{
* I am grateful for useful comments and suggestions from Jonathan Haskel, Henrik Jordahl, and Annarosa Pesole and participants at the COINVEST seminar in Mannheim and seminar at the Research Institute of Industrial Economics in Stockholm. Financial support from the European Commission is also gratefully acknowledged.

${ }^{\dagger}$ Research Institute of Industrial Economics, Box 55665, SE-102 15 Stockholm, Sweden, Phone: +468-6654599, Fax: +46-736-938408.
} 


\section{Introduction}

Most economists agree that innovations based on new technology are one of the most important generators of economic growth. Investment in new technology and knowledge is therefore believed to be crucial for economic development. During the last decades Sweden and many other countries have experienced a technological revolution based on a breakthrough in information and communication technology (ICT). The basis of the revolution was the invention of the transistor that later resulted in numerous electronic innovations, such as the semiconductor and the integrated circuit, the Internet, cell phones etc. However, whilst these new products were apparent in the market, its effect on the macroeconomic productivity growth was slow to materialize. This was named the Solow paradox after Nobel Laureate Robert Solow's famous remark that "you can see the computer age everywhere but in the productivity statistics” (Solow 1987).

In the mid 1990s productivity growth started to increase in the Swedish as well as the US economy. The increase in productivity growth was largely due to investment in ICT capital. However, although ICT investment remained important for productivity growth after the turn of the millennium, its relative impact started to decrease (Jorgenson 2008; Edquist 2008). Instead total factor productivity growth started to increase in both Sweden and the US. Thus, the productivity pick-up did not remove all suspicion about the ability of official data to accurately capture the factors that affect economic growth (Corrado, Hulten and Sichel (CHS) 2006). In a series of recent papers it has been argued that one possible explanation to the development of productivity growth could be investment in intangibles. (see CHS (2005, 2006); Marrano and Haskel (2006); Marrano, Haskel and Wallace (2007); Hao and Manole 2008).

In the Swedish national accounts intangibles have historically been treated as an intermediate expense and not as an investment. The reason has primarily been that intangibles have been considered to be very difficult to measure compared to tangible assets such as physical capital. Nevertheless, the structure of many advanced economies is generally felt to be moving towards "knowledge economy" activities, 
where intangible assets are increasingly important (Marrano and Haskel 2006). With some of the economies in the world becoming more dependent on high-tech products and knowledge intensive services, an increasing part of investment is believed to have been made in intangible assets such as education and research and development. There is no consensus of an exact definition of intangible assets. CHS $(2005,2006)$ define intangible investment as expenditures by businesses that are intended to boost output in the future but that are not traditional, tangible physical capital. Moreover, unlike physical capital, its value does not appear on the balance sheet of a firm. One reason for this is that the value of intangibles is highly uncertain. In many cases there is no competitive market for intangible assets as opposed to tangible assets.

To my knowledge, the impact of intangibles on the Swedish economy has never been explored systematically. Thus, the aim of this paper is to use the methods set up by CHS (2006) and Marrano and Haskel (2006) to estimate expenditures and investment in intangibles using Swedish data for 2004 (future work will investigate previous and future years). The following two questions will primarily be investigated:

- How large were the intangible spending and investment in the Swedish business sector in 2004?

- How large were the intangible investment in Sweden compared to other countries like the UK and the US?

The plan of the paper is as follows. Section 2 describes the method that has been used in order to collect and compare data on intangible investment. Section 3 discusses how much of the spending that could be considered as investment. Section 4 presents the results and compares them with similar findings for the UK and the US. Section 5 concludes. 


\section{Method and sources}

CHS (2006) and Marrano and Haskel (2006) focus on intangible investment in the business sector. Thus, to be able to compare their results with the Swedish data this paper will only focus on measuring investment in intangibles in the business sector. Intangible investment in the public sector is also believed to be of great importance, and will be explored in future papers. ${ }^{1}$

To measure investment in intangible assets this paper follows the methodological framework set up by CHS (2006). According to CHS intangible assets can be grouped under the following three main headings:

1. Computerized information (software, computerized databases)

2. Innovative property (scientific R\&D, mineral explorations, copyright and license cost, product development in financial industries, design, $R \& D$ in social sciences and humanities)

3. Economic competencies (brand equity, vocational training and organizational capital)

Various methods and surveys are used to estimate the spending on such assets for the year 2004. The specific methods and sources for Sweden are described below and a comparison with the corresponding methods and sources for the UK and the US are presented in table 1. It should be noted that the spending only measures the total expenditure on a specific asset and therefore in some cases includes both current consumption and deferred consumption. Only deferred consumption can be considered as investment and therefore different methods are used to separate the spending on current production from actual spending that is made to expand future productive capacity (see section 3)

\footnotetext{
${ }^{1}$ Sweden has a large public sector compared to both the US and the UK. This implies that comparisons of intangible investment in the private sector expressed as a percentage of total GDP might be effected.
} 


\subsection{Expenditure on computerized information}

\subsubsection{Computer Software}

The estimates for computer software are based on the EU KLEMS (2008). The EU KLEMS (2008) database is the result of a research project, financed by the European Commission, to analyze productivity in the European Union at the industry level. The database includes measures of output growth, employment, skill creation, capital formation and total factor productivity at the industry level. To measure investment in computer software the figures on the nominal gross fixed capital formation in software for Sweden 1993-2004 have been used. Investment for the public sector has been excluded.

\subsubsection{Computerized database}

The data of computerized information is already included in the estimates of software spending provided by the EU KLEMS (2008) database for Sweden 1993-2004.

\subsection{Innovative property}

\subsubsection{Scientific R\&D}

$R \& D$ expenditure data for Sweden is derived from the ANBERD database (OECD 2006). The ANBERD database has been constructed with the objective of creating a consistent data set that covers business enterprise expenditures on R\&D (BERD) in OECD countries. The guidelines for the collection of internationally comparable BERD data are set out by the Frescati Manual (2002). According to the Frescati Manual, R\&D is defined as "creative work undertaken on a systematic basis in order to increase the stock of knowledge, including knowledge of man, culture and society, and the use of this stock of knowledge to devise new applications”.

The basic criterion for distinguishing R\&D from other activities is that R\&D should include an appreciable element of novelty and the resolution of scientific and technological uncertainty. Thus, it is likely that most R\&D that is reported is of 
scientific nature and items such as design, market research etc. will not be included in R\&D figures. Moreover, in order to avoid double counting with the software figures, the total R\&D spending was deducted with the R\&D spending on computer and related activities.

\subsubsection{Mineral exploration}

Mineral exploration is based on data from the Geological Survey of Sweden. It primarily covers prospection of new ore deposits in the expectation of future returns (as opposed to expenditure on ore-mining to extract existing ore deposits).

\subsubsection{Copyright and license cost}

CHS (2006) proxy copyright and license costs with the development of motion pictures and that of radio, television, sound recording and book publishing. Unfortunately, there are no data available for radio, television and sound recording, thus it is assumed that the development costs for copyright and license costs are 5 times the development costs of motion pictures (see Hao and Manole 2008). The development costs of motion pictures are based on Screen Digest (2005) figures.

\subsubsection{Product development in the financial services industry}

Product development in the financial services industry is measured by CHS as 20 percent of total intermediate spending by financial services. We therefore use the measure of intermediate service input which excludes intermediate spending in the manufacturing sector. According to Haskel (2006) one problem is that intermediate spending includes the purchase of advertising, software, consulting services and architectural and engineering activities which is calculated elsewhere in the spending calculations. Unfortunately it is not possible to subtract spending on these activities from the Input-Output tables, because there is only data available at the 2-digit output level. The source of the intermediate service spending is EU KLEMS. 


\subsubsection{New architectural and engineering design}

It is important to be aware of what is meant by design before trying to quantify the extent of design as an economic activity. Distinguishing design from other activities matters because several design-related activities are already counted in the formation of capital in the National Accounts. According to Marrano and Haskel (2006) a good starting point to define the design activity is the relationship between design activities and the official measurement of R\&D under the Frescati Manual framework. According to the latter if design is made for the setting up and operating of pilot plants and prototypes, these costs should be included in R\&D. However, if they are carried out for the preparation, execution and maintenance of production standardization or to promote the sale of products, they should be excluded from the definition of R\&D.

The System of National Accounts (1993) sets out the convention regarding the treatment of design services. Accordingly, these are fully used up or fully transformed by the production process. This implies that design services are treated in most cases as intermediate consumption, not as capital investment. It also implies the costs of inhouse design activities are deemed not to generate an independent output and so not counted as a separate product.

In CHS half of the turnover of the architectural and design industry was used as a proxy for purchased and own account expenditure on architectural and engineering design (AED). However, in this paper both purchased and own account design activities are estimated by more sophisticated methods. Thus, the AED services bought in the marketplace and the AED services which companies produce in-house for internal use will me measured.

Galindo-Rueda, Haskel and Pesole (GHP) (2008) estimate the spending on design in the UK by using wages earned by designers and supply-use tables for the product group Architectural activities and technical consultancy. Unfortunately, it has not been possible to obtain supply-use tables for Sweden at the disaggregated level that is needed to measure the supply of architectural activities and technical consultancy 
services. Thus, the methods used in this paper will differ from the methods developed by GHP (2008).

The AED services brought in the market place are estimated as the output of the Architectural activities and technical consultancy industry (SIC 742). Due to the lack of supply-use tables, it has not been possible to estimate how much of the market design services that are actually produced by SIC 742. Nonetheless the total output is weighted by the share of the total proportion of employment in SIC 742 that is related to design occupations. Based on Galindo-Rueda, Haskel and Pesole (2008) the following occupations have been defined as design occupations: Architects and town planners (SSYK 2141), Civil engineers (SSYK 2142), Electrical engineers (SSYK 2143), Electronics and telecommunications engineers (SSYK 2144), Mechanical engineers (SSYK 2145), Chemical engineers (SSYK 2146), Designers (SSYK 2456) and Decorators and commercial designers (SSYK 3471). ${ }^{2}$ Thus the spending on purchased design activities can be written ${ }^{3}$ :

$$
Y_{p}=Y^{742} \cdot \frac{N^{742 A E D}}{N^{742}}
$$

Where, $Y_{p}$ is the measured purchased AED output, $Y^{742}$ is the output of SIC 742 and $N^{742 A E D}$ is the number of employees with design occupations and $N^{742}$ is the number of employees in SIC 742.

To estimate the own-account by industries outside of design we use the wage bill of designers working outside the design industry (SIC 74.2). The ratio of purchases output to the wage bill in the design sector is calculated and this ratio is then multiplied with the wage bill of designers in the business sector excluding SIC 74.2. This can be expressed in the following formula:

$$
Y_{\text {own }}=\frac{Y_{p}}{w N^{742 A E D}} \cdot w N^{B A E D}
$$

\footnotetext{
${ }^{2}$ SSYK is the Swedish Standard Classification of Occupations.

${ }^{3}$ For some engineering occupations it is likely that the employees to some extent is also involved in R\&D activities which then implies double counting.
} 
Where $Y_{\text {own }}$ is the own account output, $Y_{p}$ the purchased output, $w N^{742 A E D}$ the wage bill of designers in SIC 74.2, $w N^{B A E D}$ is the wage bill of designers in the business sector excluding SIC 74.2.

\subsubsection{R\&D in social sciences and humanities}

Estimates of R\&D in social sciences and humanities are based on R\&D data from Statistics Sweden. To capture own account spending the expenditure is multiplied with a factor of 2 .

\subsection{Economic competences}

\subsubsection{Brand equity}

\subsubsection{Advertising}

Data on spending on advertising is based on the Swedish Institute for Advertisement (IRM). Data on classified ads were deducted based on figures for 2007. Classified ads then accounted for approximately 8 percent of total advertisement and 35 percent of the advertisement in newspapers.

The available data includes the public sector. Thus, it is assumed that the public sector accounts for a certain percentage of the advertisement investment. According to a survey by SIFO Research International approximately 1.1 percent of all advertisement investments were made by the government sector in 2007. Hence, the total investment is deducted by 1.1 percent for each year. However, this does not include the investments made by "Svenska Spel”, the state-owned gambling company.

\subsubsection{Market Research}

Expenditure on market research is measured as twice the turnover of the Market and consumer research industry (ISIC 7413). The estimation is based on the assumption that own account market research equals purchased market research. 


\subsubsection{Firm-specific human capital}

Firm specific human capital is measured using data on how many firms in the business sector spent on continuing vocational training. The source is a survey of employer provided training conducted by Statistics Sweden in 1999 (CVTS 1999). A similar survey was carried out in 2005, but it was never published by Statistics Sweden due to a low response ratio.

CVTS (1999) measures the direct and indirect costs of continuing vocational training in firms with at least 10 employees as a percentage of total labor costs in 1999. Thus, to measure the spending on vocational training for all firms it is assumed that firms with less than 10 employees spend the same proportion of their total labor costs on vocational training. Moreover, it is assumed that the proportion of labor costs spend by firms in 1999 is the same as in 2004 . This assumption must be made due to the fact that reliable data on continuing vocational training is only available for the year 1999 .

\subsubsection{Organizational structure}

\subsubsection{Purchased organizational structure}

Investment in organizational structure (OS) includes investment in purchased OS and own account OS. Purchased OS is measured with the revenues of the management consulting industry. The data is based on a yearly survey made by Affärsvärlden, which is a Swedish business magazine. Public sector was excluded based on the data provided by Affärsvärlden.

\subsubsection{Own account organizational structure}

Investment in own-account organizational structure is measured as 20 percent of managers' compensation. The occupation used for managers is “Legislators, senior officials and managers”. However, since the public sector is excluded legislators and senior government officials are excluded, but senior officials working for specialinterest organizations are still included. 


\section{How much of the spending is investment}

According to CHS (2005, 2006) and Marrano, Haskel and Wallis (2007) not all spending on intangibles can be considered as investment. It is necessary to separate the expense of current production from outlays that expand future productive capacity. For physical capital this distinction is often made on the basis of the durability or expected service life of a purchase. The service life of a specific asset can sometimes be ambiguous. For example the definition used by the Bureau of Economic Analysis (BEA) might differ depending on the sector that is considered. The BEA approximate that business fixed assets have a useful service life of at least three years, but there are also studies defining business sector equipment as having a service life of more than one year.

Based on this logic CHS (2005) use four different steps to estimate the proportion of spending that can be considered as investment.

1. If economic research has clearly shown that a given type of spending is fixed investment, then 100 percent is classified as capital investment.

2. If economic research suggests that only a portion of the spending on an intangible pays off in future year (or years), these findings are applied.

3. When there is a strong suspicion that the lifetime of a type of intangible may not be at least three years, the item is discounted by 20 percent and a range of estimates of capital investment is shown for the item.

4. When there is a strong suspicion that a portion of the spending may be of routine tasks or represent current consumption, the point estimate is discounted 20 percent.

It is recognized that these steps do not provide a precise measure of the spending that can be considered to be capital investment. Especially the last two steps are vague and the discounted percentage is arbitrary. Nevertheless, in total the results by CHS (2005) show that business spending on intangibles was a substantial and growing 
component of the economy in the 1990s. Though, it is essential that future research try to improve these methods.

Table 2 shows the proportion of spending considered as investment based on CHS (2005). Little is known about the service life of software. However, the BEA assumes three years service life for all prepackaged software and a five year service life for custom and owned software. Therefore CHS (2006) assume that 100 percent of the total spending on computerized information should be classified as capital investment. The same rule applies for scientific R\&D spending, mineral exploration, copyright and license costs, development in financial services and R\&D in social sciences. However, based on estimates provided by Galindo-Rueda, Haskel and Pesole (2008) only 50 percent of design spending should be counted as investment.

Economic research on marketing finds that the effects of advertising are generally short lived. However, according to Landes and Rosenfield (1994) more than half has a service life of at least one year and one-third makes a cutoff of three years. Thus, CHS (2005) estimate that approximately 60 percent of total advertising expenditures have long lasting effects. Continuing vocational training has long lived effects and is therefore counted as investment. Spending on organizational change is also likely to have long-lived effects, but a portion of management fees is not capital spending, but rather routine tasks and therefore only 80 percent of the own-account organizational spending is considered as investment.

It is evident that the process of estimating how large part of the spending that is actually investment in many cases is not very precise but rather based on ad hoc assumptions. Nevertheless, it is of importance to use the best available information to try to measure investment in intangibles. Moreover, for some of the more important types of intangibles like scientific $R \& D$ and vocational training the service life is without doubt at least 3 years and 100 percent of the spending should therefore be counted as investment. 


\section{Results}

\subsection{Results for Sweden}

Figure 1 shows that the total spending on intangibles in Sweden in 2004 was 277 billion SEK. Thus, the spending was approximately 10.6 percent of total GDP and 16.2 percent of total value added in the business sector. Based on the method developed by CHS (2005) and described in section 3, it is estimated that 227 of the 277 billion could be accounted as investment. The Swedish investment in fixed capital for the business sector in 2004 was 361 billion SEK. Hence, the estimated investment in intangibles was almost two-thirds of the investment in physical capital. This clearly shows that investment in intangibles was considerable in comparisons with investment in physical capital.

Table 2 shows the spending for the different types of intangibles. The largest expenditure was on scientific R\&D with 68 billion or 25 percent of total spending on intangibles. This corresponds well with the general view that Sweden is considered to be an R\&D-intensive country. Spending was also considerable for design, software, advertising and vocational training. In fact, together with scientific R\&D these types of assets accounted for almost 90 percent of the total spending on intangibles.

Spending on own account organizational structure was 12 billion SEK and thereby accounted for 4 percent of total spending. For all other types of intangibles the spending was less than 2 percent of the total expenditure on intangibles. For mineral exploration and $R \& D$ in social sciences the spending was as low as 0.1 percent of the total spending.

\subsection{Comparisons with other countries}

Figure 2 shows the private spending on intangibles as a percentage of GDP in Sweden, the UK and the US for the three major intangible asset categories: computerized information, innovative property and economic competencies. All countries spent close to similar amounts on software. However, Sweden spent more than the other countries in relative terms on innovative property, but the spending on 
economic competencies was much lower in Sweden compared to the other countries. In fact, the US spent almost twice as much on economic competencies.

Table 3 presents the results of spending on intangibles as a percentage of GDP for all sub-categories. Table 3 shows that spending on scientific R\&D was higher in Sweden than in the US and considerably higher than in the UK. Swedish private spending on scientific R\&D accounted for 2.6 percent of GDP. Hence, Sweden spent more than twice as much as the UK on scientific R\&D. The US spent considerably more on copyright and licence costs than Sweden and the UK. Development costs in the financial industry were also higher in the US and the UK compared to Sweden, while the design industry was considerably larger in Sweden.

Sweden spent approximately the same amount as the UK on advertisement, but a considerably larger amount was spent in the US economy. Moreover, Swedish and US firms spent a little bit more than 1 percent of GDP on vocational training, while the UK spending was 2.5 percent. Spending on organizational structure was very low in Sweden compared to the other countries. Both purchased and own account spending on organizational structure was more than 4 times higher in the US. However, the way own account organizational structure is measured poses some doubts about what is measured. For example in US managers are in general better paid than their Swedish colleagues, but it does not necessarily mean that they are more productive.

In total the US had the highest private spending on intangibles in relative terms with 13 percent of GDP. For Sweden and the UK the corresponding figures were approximately 10 percent. Hence, the spending on intangibles was higher in the US, but was also a considerably larger share of GDP in the UK and Sweden. However, since Sweden has a larger public sector than the US and the UK, it is possible that its relative spending on intangibles would be higher if only value added for the business sector was considered.

Figure 3 shows the spending on intangibles as a share of value added in the business sector for the three countries. The Swedish spending on intangibles was 16.2 percent, while the corresponding figures for the UK and the US were 15.9 and 17.9 percent, respectively. Thus, in relative terms the Swedish spending was larger than the British 
and the gap to the US decreased when the business sector was considered instead of total GDP. This is explained by the fact that the public sector in Sweden is larger than in the two other countries.

\section{Conclusions}

This paper has tried to measure spending and investment in intangibles in the Swedish business sector in 2004. Although the methodological framework must undergo improvements the results show that intangibles are quantitatively important. They show that the total private spending on intangibles was 277 billion SEK which is equivalent to 10.6 percent of GDP or 15.5 percent of value added in the business sector. Thus, spending on intangibles accounted for a considerable share of total GDP and thus is very important for understanding economic development.

Based on the method in CHS (2005), 227 of the 277 billion of spending on intangibles could be considered as investment. The corresponding figure for physical capital in the business sector was 361 billion, which implies that investment in intangibles accounted for approximately two-thirds of the investment in physical capital.

Scientific R\&D, design, software, advertising and vocational training accounted for almost 90 percent of the total investment in intangibles. Development in financial services, organizational structure, $R \& D$ in social sciences and humanities and mineral exploration and copyright and license costs had a much smaller impact on the total spending and investment in intangibles.

In comparison with other countries, Sweden and the UK had approximately the same spending on intangibles in terms of GDP with 10.6 and 10.9 percent, respectively. The spending was higher in the US with 13.1 percent of GDP. However, in terms of spending as a share of value added in the business sector the spending was slightly higher in Sweden compared to the UK and the gap to the US decreased. The spending for Sweden and the UK was approximately 16 percent of value added in the business sector, while it was 18 percent for the US. Moreover, Sweden had very high spending 
on R\&D compared to the other two countries. Thus, in relative terms Sweden is an $\mathrm{R} \& \mathrm{D}$ intensive country.

Approximately the same amount was spent on computer software in the three countries. Spending on organizational structure was very low in Sweden. In fact it was almost five times higher in the US. This could of course partly be explained by higher wages for managers in the US. Nonetheless, the result indicates that the differences are huge and therefore should be further analyzed.

It is evident that much future work must be done to improve the estimates presented in this paper. The largest caveat is that investment in company organizational capital is of great importance, but there is no good and exact measure of it. Thus, measurement issues must remain an important topic for future research in this area. Despite the measurement errors the result clearly indicates that investment in intangibles is of great importance. Thus, as measurement methods are improved, Statistical Offices should consider including investment in intangibles in the National Accounts.

\section{Tables and figures}

\subsection{Tables}

Table 1 Sources and methods

\begin{tabular}{|c|c|c|c|}
\hline $\begin{array}{l}\text { Type of intangible } \\
\text { investment }\end{array}$ & CHS method & $\begin{array}{c}\text { Marrano and } \\
\text { Haskel method }\end{array}$ & Current paper \\
\hline $\begin{array}{l}\text { Computerized } \\
\text { information }\end{array}$ & US & UK & Sweden \\
\hline Computer software & $\begin{array}{l}\text { Covers expenses of } \\
\text { software developed for } \\
\text { a firm's own use. } \\
\text { Based on NIPA data } \\
\text { that includes three } \\
\text { components: own use, } \\
\text { purchased, and custom } \\
\text { software. }\end{array}$ & $\begin{array}{l}\text { Based on National } \\
\text { Accounts, using } \\
\text { OECD method, } \\
\text { includes own use, } \\
\text { purchased and } \\
\text { custom software. }\end{array}$ & $\begin{array}{l}\text { Based on EU } \\
\text { KLEMS database, } \\
\text { includes nominal } \\
\text { gross fixed capital } \\
\text { formation in } \\
\text { software. }\end{array}$ \\
\hline
\end{tabular}




\begin{tabular}{|c|c|c|c|}
\hline Computerized databases & $\begin{array}{l}\text { Own use likely is } \\
\text { captured in NIPA } \\
\text { software measures; } \\
\text { data from the Services } \\
\text { Annual Survey (SAS) } \\
\text { suggest that the } \\
\text { purchased component } \\
\text { is small. }\end{array}$ & $\begin{array}{l}\text { Included in } \\
\text { software estimates }\end{array}$ & $\begin{array}{l}\text { Included in } \\
\text { software } \\
\text { estimates }\end{array}$ \\
\hline Innovative property & & & \\
\hline Scientific R\&D & $\begin{array}{l}\text { Mainly R\&D in } \\
\text { manufacturing, } \\
\text { software publishing, } \\
\text { and telecom industries. } \\
\text { The industrial R\&D } \\
\text { data are available from } \\
\text { the early 1950s and } \\
\text { cover work in the } \\
\text { physical sciences, the } \\
\text { biological sciences, and } \\
\text { engineering and } \\
\text { computer science (but } \\
\text { excluding geophysical, } \\
\text { geological, artificial } \\
\text { intelligence, and } \\
\text { expesystems research). }\end{array}$ & $\begin{array}{l}\text { ONS Business } \\
\text { Performed R\&D } \\
\text { (BERD). Reported } \\
\text { R\&D in computer } \\
\text { industries } \\
\text { subtracted in case } \\
\text { of double counting } \\
\text { with software data }\end{array}$ & $\begin{array}{l}\text { Based on } \\
\text { ANBERD } \\
\text { database. } \\
\text { Reported R\&D in } \\
\text { computer and } \\
\text { related activities } \\
\text { has been } \\
\text { subtracted to } \\
\text { avoid double } \\
\text { counting with } \\
\text { software data. }\end{array}$ \\
\hline Mineral exploration & $\begin{array}{l}\text { Mainly R\&D in mining } \\
\text { industries. a. Mineral } \\
\text { exploration, Census of } \\
\text { Mineral Industries and } \\
\text { NIPAs. b. Other } \\
\text { geophysical and } \\
\text { geological exploration } \\
\text { R\&D in mining } \\
\text { industries, estimated } \\
\text { from Census data }\end{array}$ & $\begin{array}{l}\text { National Accounts, } \\
\text { ONS series }\end{array}$ & $\begin{array}{l}\text { Geological } \\
\text { Survey of Sweden }\end{array}$ \\
\hline $\begin{array}{l}\text { Copyright and license } \\
\text { costs }\end{array}$ & $\begin{array}{l}\text { Attempts to capture } \\
\text { R\&D in information } \\
\text { sector industries } \\
\text { (except software } \\
\text { publishing). No broad } \\
\text { statistical information, } \\
\text { proxied by: a. } \\
\text { Development costs in } \\
\text { the motion picture } \\
\text { industry, estimated } \\
\text { using data from the } \\
\text { Motion Picture } \\
\text { Association of America } \\
\text { (MPAA) } \\
\text { b. Development costs }\end{array}$ & $\begin{array}{l}\text { National Accounts, } \\
\text { ONS series. Data } \\
\text { are those used by } \\
\text { National Accounts } \\
\text { to capitalize } \\
\text { spending in TV and } \\
\text { radio, publishing } \\
\text { and music } \\
\text { industries }\end{array}$ & $\begin{array}{l}\text { Based on Screen } \\
\text { Digest. It is } \\
\text { assumed that the } \\
\text { development } \\
\text { costs for } \\
\text { copyright and } \\
\text { license costs are } 5 \\
\text { times the } \\
\text { development } \\
\text { costs of motion } \\
\text { pictures. }\end{array}$ \\
\hline
\end{tabular}




\begin{tabular}{|c|c|c|c|}
\hline & $\begin{array}{l}\text { in the radio and } \\
\text { television, sound } \\
\text { recording, and book } \\
\text { publishing industries } \\
\text { are crudely estimated to } \\
\text { be double the new } \\
\text { product development } \\
\text { costs for motion } \\
\text { pictures. (No estimate } \\
\text { for the arts is included.) }\end{array}$ & & \\
\hline $\begin{array}{l}\text { New product } \\
\text { development costs in the } \\
\text { financial industry }\end{array}$ & $\begin{array}{l}\text { Estimated as } 20 \text { percent } \\
\text { of intermediate } \\
\text { purchases. }\end{array}$ & $\begin{array}{l}\text { Estimated as 20\% } \\
\text { of Financial } \\
\text { Services industry's } \\
\text { intermediate } \\
\text { purchases (ONS } \\
\text { data), discounting } \\
\text { advertising, } \\
\text { software, } \\
\text { consulting and } \\
\text { design purchases . }\end{array}$ & $\begin{array}{l}\text { Based on EU } \\
\text { KLEMS database. } \\
\text { Estimated as 20\% } \\
\text { of Financial } \\
\text { Services } \\
\text { industry's } \\
\text { intermediate } \\
\text { purchases. It has } \\
\text { not been possible } \\
\text { to discount } \\
\text { advertising, } \\
\text { software, } \\
\text { consulting and } \\
\text { design purchases }\end{array}$ \\
\hline $\begin{array}{l}\text { New architectural and } \\
\text { engineering design }\end{array}$ & $\begin{array}{l}\text { New architectural and } \\
\text { engineering designs, } \\
\text { estimated as half of } \\
\text { industry purchased } \\
\text { services (revenues of } \\
\text { the industry as reported } \\
\text { in SAS). }\end{array}$ & $\begin{array}{l}\text { Purchased are } \\
\text { estimated for the IO } \\
\text { tables. Own- } \\
\text { account is } \\
\text { estimated using } \\
\text { designers' earnings } \\
\text { from ASHE data. } \\
\text { Investment is } \\
\text { estimated as } 50 \% \text { of } \\
\text { these expenditure } \\
\text { totals. }\end{array}$ & $\begin{array}{l}\text { Based on wage } \\
\text { bill and output } \\
\text { data from } \\
\text { Statistics Sweden. } \\
\text { Purchased } \\
\text { estimated as the } \\
\text { output of SIC } \\
74.2 \text { multiplied } \\
\text { with the ratio of } \\
\text { design employees } \\
\text { and total } \\
\text { employees in SIC } \\
74.2 \text {. Own } \\
\text { account is } \\
\text { estimated using } \\
\text { the output-wage } \\
\text { bill ratio of } \\
\text { designers in SIC } \\
74.2 \text { multiplied } \\
\text { with designers' } \\
\text { wage bill in the } \\
\text { rest of the } \\
\text { business sector. }\end{array}$ \\
\hline $\begin{array}{l}\text { R\&D in social sciences } \\
\text { and humanities }\end{array}$ & $\begin{array}{l}\text { R\&D in social sciences } \\
\text { and humanities, } \\
\text { estimated as twice }\end{array}$ & $\begin{array}{l}\text { Estimated as twice } \\
\text { industry revenues } \\
\text { of social science }\end{array}$ & $\begin{array}{l}\text { Based on R\&D } \\
\text { data from } \\
\text { Statistics Sweden. }\end{array}$ \\
\hline
\end{tabular}




\begin{tabular}{|c|c|c|c|}
\hline & $\begin{array}{l}\text { industry purchased } \\
\text { services (revenues as } \\
\text { reported in SAS) }\end{array}$ & $\begin{array}{l}\text { and humanities } \\
\text { R\&D industry } \\
\text { (73.2) from ONS } \\
\text { services inquiry }\end{array}$ & $\begin{array}{l}\text { Estimated as } \\
\text { twice the turnover } \\
\text { of R\&D in the } \\
\text { social science and } \\
\text { humanities } \\
\text { industry (SIC } \\
732 \text { ) }\end{array}$ \\
\hline \multirow{2}{*}{$\begin{array}{l}\text { Economic } \\
\text { competencies } \\
\text { Brand equity } \\
\text { Advertising expenditure }\end{array}$} & & & \\
\hline & $\begin{array}{l}\text { Purchases of } \\
\text { advertising services; } \\
\text { advertising } \\
\text { expenditures, grand } \\
\text { total by type of } \\
\text { advertiser as reported } \\
\text { by Universal-McCann } \\
\text { (data begin in 1935) }\end{array}$ & $\begin{array}{l}\text { Estimates from } \\
\text { Advertising } \\
\text { Association on } \\
\text { spending adverts in } \\
\text { newspapers, films, } \\
\text { roadsides etc. } \\
\text { Classified } \\
\text { advertising } \\
\text { excluded. }\end{array}$ & $\begin{array}{l}\text { Based on the } \\
\text { Swedish Institute } \\
\text { for Advertisement } \\
\text { (IRM). Classified } \\
\text { advertising has } \\
\text { been excluded } \\
\text { based on data for } \\
2007 \text {. }\end{array}$ \\
\hline Market Research & $\begin{array}{l}\text { Outlays on market } \\
\text { research, estimated as } \\
\text { twice industry } \\
\text { purchased services } \\
\text { (revenues of the market } \\
\text { and consumer research } \\
\text { industry as reported in } \\
\text { SAS). }\end{array}$ & $\begin{array}{l}\text { Estimated from the } \\
\text { IO tables. We then } \\
\text { double the figures } \\
\text { to consider the } \\
\text { own-account }\end{array}$ & $\begin{array}{l}\text { Estimated as } \\
\text { twice the turnover } \\
\text { of the market and } \\
\text { consumer } \\
\text { research industry } \\
\text { (ISIC 7413) } \\
\text { reported by } \\
\text { Statistics Sweden }\end{array}$ \\
\hline $\begin{array}{l}\text { Firm-specific human } \\
\text { capital }\end{array}$ & $\begin{array}{l}\text { Broad surveys of } \\
\text { employer-provided } \\
\text { training were } \\
\text { conducted by the } \\
\text { Bureau of Labor } \\
\text { Statistics (BLS) in } \\
1994 \text { and 1995. } \\
\text { a. Direct firm expenses } \\
\text { (in-house trainers, } \\
\text { outside trainers, tuition } \\
\text { reimbursement, and } \\
\text { outside training funds) } \\
\text { b. W age and salary } \\
\text { costs of employee time } \\
\text { in formal and informal } \\
\text { training. }\end{array}$ & $\begin{array}{l}\text { Almost identical } \\
\text { survey to US } \\
\text { carried out in } 2005 \\
\text { as supplement to } \\
\text { National Employer } \\
\text { Skills Survey. } \\
\text { Gives expenses and } \\
\text { costs of employee } \\
\text { time for employer } \\
\text { provided training. }\end{array}$ & $\begin{array}{l}\text { Based on survey } \\
\text { of employer } \\
\text { provided training } \\
\text { (CVTS2) } \\
\text { conducted by } \\
\text { Statistics Sweden } \\
\text { in } 1999 .\end{array}$ \\
\hline $\begin{array}{l}\text { Purchased } \\
\text { organizational structure }\end{array}$ & $\begin{array}{l}\text { Purchased } \\
\text { "organizational" or } \\
\text { "structural” capital, } \\
\text { estimated using SAS } \\
\text { data on the revenues of } \\
\text { the management }\end{array}$ & $\begin{array}{l}\text { Data on revenues of } \\
\text { management } \\
\text { consulting industry } \\
\text { from Management } \\
\text { Consulting } \\
\text { Association. }\end{array}$ & $\begin{array}{l}\text { Data of revenues } \\
\text { of management } \\
\text { consulting } \\
\text { industry based on } \\
\text { the Swedish } \\
\text { business }\end{array}$ \\
\hline
\end{tabular}




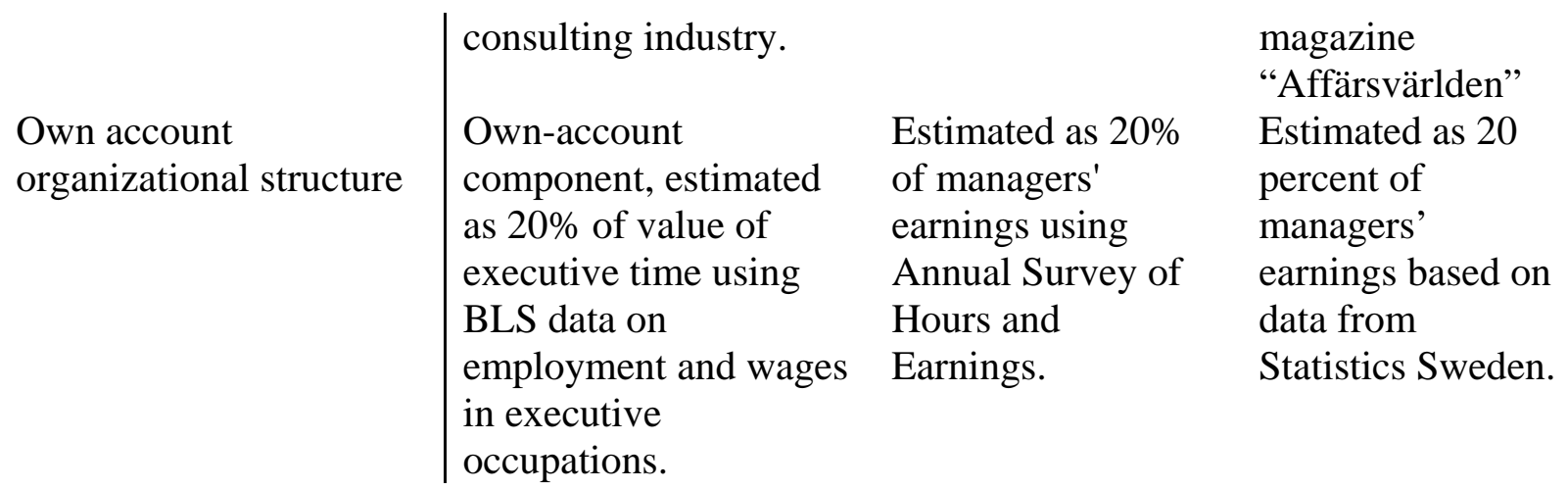

Sources: CHS (2006) Marrano and Haskel (2007). 
Table 2 Intangibles in Sweden 2004

\begin{tabular}{|c|c|c|c|c|}
\hline Type of intangible investment & Source & $\begin{array}{l}\text { Total } \\
\text { spending } \\
2004 \text { (bn } \\
\text { SEK) }\end{array}$ & $\begin{array}{l}\text { Percent of } \\
\text { intangibles }\end{array}$ & $\begin{array}{l}\text { Proportion of } \\
\text { spending } \\
\text { considered as } \\
\text { investment }\end{array}$ \\
\hline 1. Computerized information & & 48.2 & 17.4 & \\
\hline a) Computer software & EU-KLEMS & 48.2 & 17.4 & 1 \\
\hline b) Computerized databases & $\begin{array}{l}\text { Included in } \\
\text { computer software }\end{array}$ & n.a. & 0 & 1 \\
\hline 2. Innovative property & & 141.5 & 51.1 & \\
\hline a) Scientific R\&D & OECD ANBERD & $68.0 *$ & 24.6 & 1 \\
\hline b) Mineral exploration & $\begin{array}{l}\text { SGU (Geological } \\
\text { Survey of } \\
\text { Sweden) }\end{array}$ & 0.25 & 0.1 & 1 \\
\hline c) Copyright and license costs & Screen Digest & 2.9 & 1.0 & 1 \\
\hline $\begin{array}{l}\text { d) Development costs in } \\
\text { financial industry }\end{array}$ & EU-KLEMS & 6.6 & 2.4 & 1 \\
\hline $\begin{array}{l}\text { e) New architectural and } \\
\text { engineering design }\end{array}$ & Statistics Sweden & 63.5 & 22.9 & 0.5 \\
\hline $\begin{array}{l}\text { f) R\&D in social sciences and } \\
\text { humanities }\end{array}$ & Statistics Sweden & $0.21^{* *}$ & 0.1 & 1 \\
\hline $\begin{array}{l}\text { 3. Economic competencies } \\
\text { a) Brand equity }\end{array}$ & & 87.1 & 31.5 & \\
\hline Advertisement & $\begin{array}{l}\text { Swedish Institute } \\
\text { for Advertisement } \\
\text { (IRM) }\end{array}$ & 37.4 & 13.5 & 0.6 \\
\hline Market Research & Statistics Sweden & 4.7 & 1.7 & 0,6 \\
\hline $\begin{array}{l}\text { b) Firm-specific human capital } \\
\text { c) Organizational structure }\end{array}$ & Statistics Sweden & 27.6 & 10.0 & \\
\hline Purchased & Affärsvärlden & 5.1 & 1.9 & 0.8 \\
\hline Own-account & Statistics Sweden & 12.2 & 4.4 & 1 \\
\hline Total Spending & & 276.9 & 100 & \\
\hline
\end{tabular}

Note: *To avoid double counting the investment in R\&D is deducted with the R\&D investment for computer and related activities. The latter is based on the year 2003 while total scientific R\&D investment is based on the year 2004. **Since Statistics Sweden only report investment figures for R\&D every other year, the figure refers to the average R\&D investment in 2003 and 2005.

Sources: See “Source” in table above. 
Table 3 Percentage of GDP spending on intangible assets in Sweden and the UK in 2004 and the US in 1998-2000

\begin{tabular}{l|ccc}
\hline Type of intangible investment & Sweden & US & UK \\
\hline 1. Computerized information & $\mathbf{1 . 8 3}$ & $\mathbf{1 . 6 5}$ & $\mathbf{1 . 7 0}$ \\
a) Computer software & n.a. & n.a. & n.a. \\
b) Computerized databases & n.a. & n.a. & n.a. \\
& & & \\
2. Innovative property & $\mathbf{5 . 3 9}$ & $\mathbf{4 . 5 7}$ & $\mathbf{3 . 2 3}$ \\
a) Scientific R\&D & 2.59 & 2.06 & 1.06 \\
b) Mineral exploration & 0.01 & 0.19 & 0.04 \\
c) Copyright and license costs & 0.11 & 0.81 & 0.21 \\
d) Development costs in financial industry & 0.25 & 0.79 & 0.69 \\
e) New architectural and engineering design & 2.42 & 0.73 & 1.20 \\
f) R\&D in social sciences and humanities & 0.01 & 0.08 & 0.03 \\
& & & \\
3. Economic competencies & 3.32 & $\mathbf{6 . 9 1}$ & $\mathbf{5 . 9 5}$ \\
a) Brand equity & 1.61 & 2.53 & 1.59 \\
$\quad$ Advertisement & 1.43 & 2.33 & 1.20 \\
$\quad$ Market Research & 0.18 & 0.20 & 0.39 \\
b) Firm-specific human capital & 1.05 & 1.25 & 2.45 \\
c) Organizational structure & 0.66 & 3.13 & 1.92 \\
$\quad$ Purchased & 0.20 & 0.87 & 0.60 \\
$\quad$ Own-account & 0.47 & 2.26 & 1.31 \\
Percent of total GDP & $\mathbf{1 0 . 5 5}$ & $\mathbf{1 3 . 1 3}$ & $\mathbf{1 0 . 8 8}$ \\
\hline
\end{tabular}

Sources: CHS (2006), Marrano and Haskel (2007) and own calculations. 


\subsection{Figures}

Figure 1 Business sector spending and investment in intangible capital and physical capital in Sweden in 2004

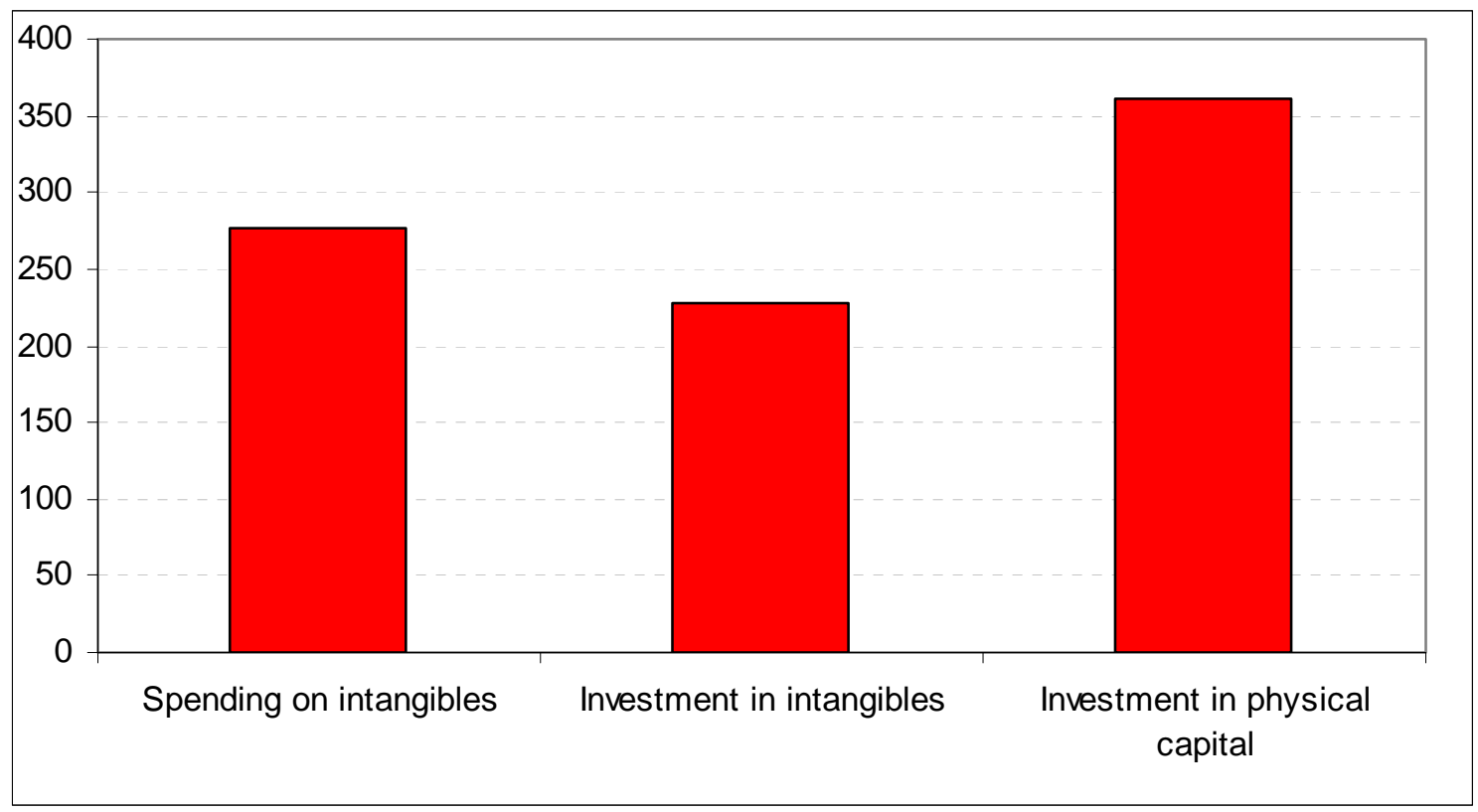

Sources: Own calculations based on the framework in CHS (2006) and Marrano and Haskel (2007).

Figure 2 Business sector spending on intangibles in three countries (percent of GDP)

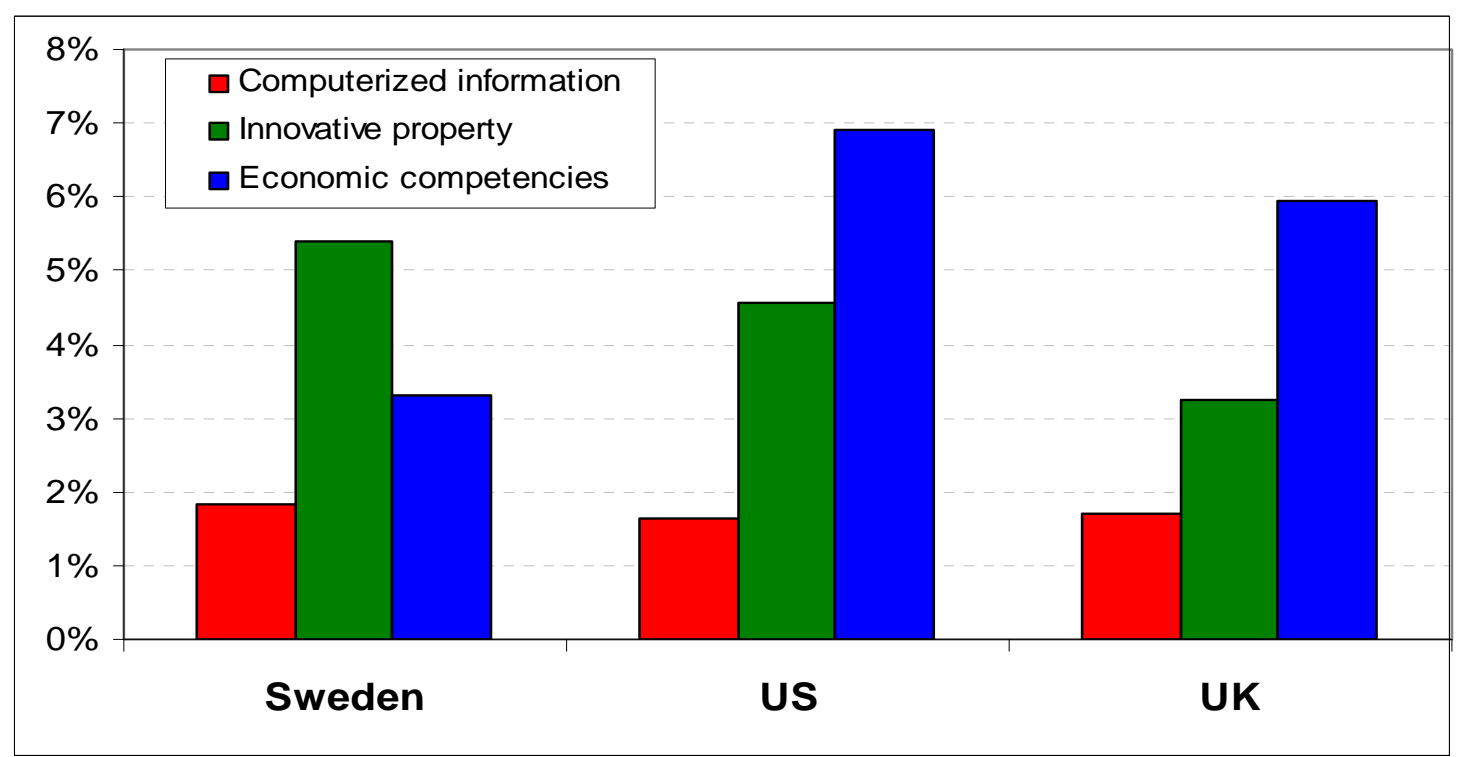

Sources: CHS (2006), Marrano and Haskel (2007) and own calculations. 
Figure 3 Spending on intangibles as a share of total value added in the business sector and total GDP for Sweden, the UK and the US (percent)

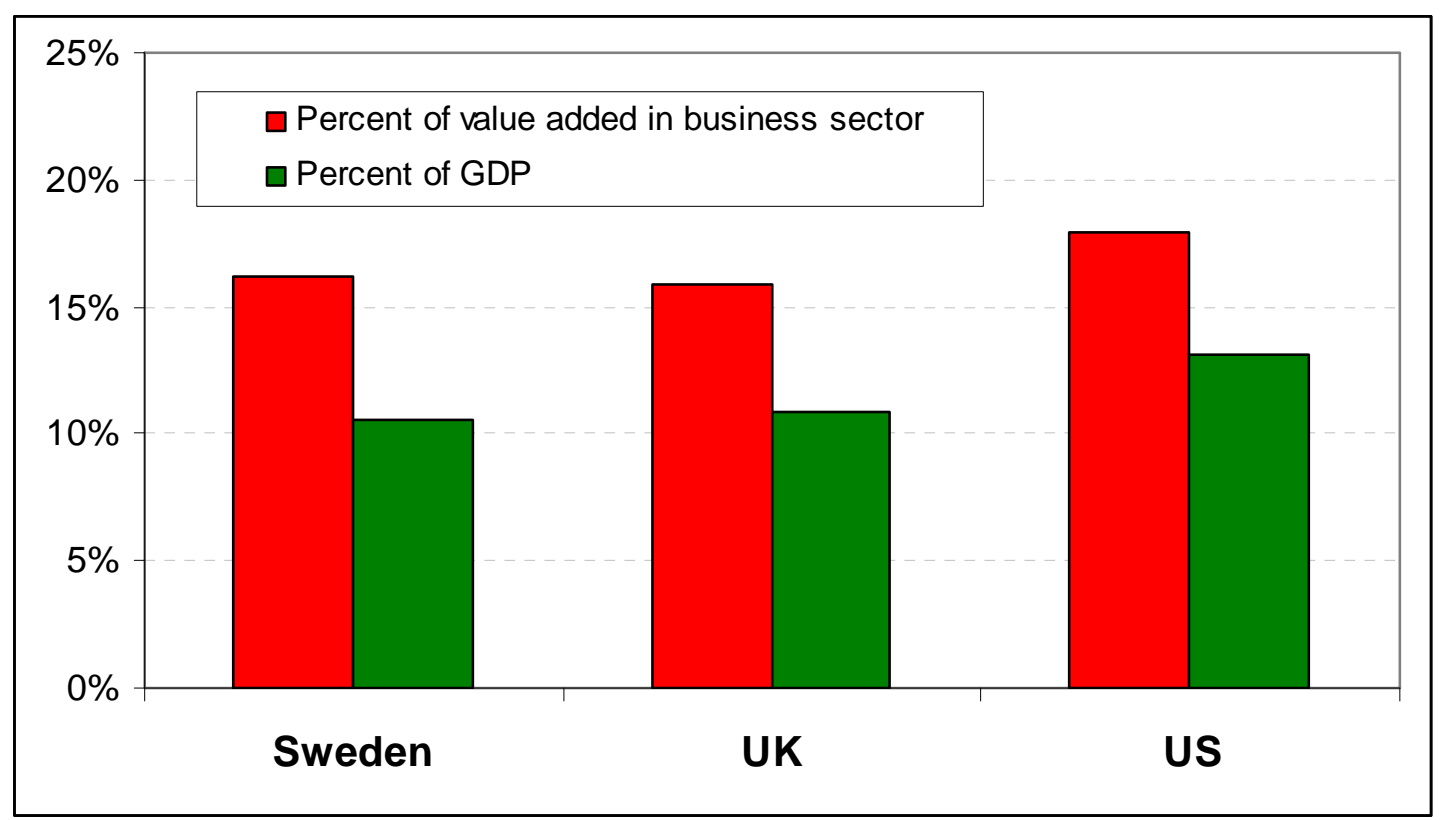

Sources: EU KLEMS (2008), CHS (2006), Marrano and Haskel (2007) and own calculations. 


\section{References}

Corrado, Carol, Hulten, Charles and Sichel, Daniel (2005), 'Measuring Capital and Technology: An Expanded Framework', In: Corrado, Carol, Haltiwanger, John and Sichel, Daniel (eds), Measuring Capital in the New Economy, National Bureau of Economic Research Studies in Income and Wealth, Vol. 65, pp. 11-45, The University of Chicago Press, Chicago and London.

Corrado, Carol, Hulten, Charles and Sichel, Daniel (2006), "The Contribution of Intangible Investments to US Economic Growth: A Sources-of-growth Analysis”, NBER Working Paper. No. 11948.

CVTS (1999), Continuing vocational training survey for Sweden, Statistics Sweden, www.scb.se

Edquist, Harald (2008), “Svensk produktivitetsutveckling och förutsättningar för en framgångsrik IKT-politik”, IFN Policy Paper, No. 23, Stockholm.

EU KLEMS (2008), EU KLEMS Database, March 2008, www.euklems.net

Frescati Manual (2002), Frescati Manual: Proposed Standard Practice for Surveys on Research and Experimental Development, OECD, Paris.

Galindo-Rueda, Fernando, Haskel, Jonathan and Pesole, Annarosa (2008), "How much does the UK employ, spend and invest in design?”, CeRiBA Working paper, April.

Gil, Valentina and Haskel, Jonathan (2007), “Industry-level Expenditure on Intangible Assets in the UK”, Working paper.

Hao, Janet X. and Manole, Vlad (2008), "Intangible Capital and Growth - an International Comparison”, The Conference Board, August.

Jorgenson, Dale W, Ho, Mun S. och Stiroh, Kevin J. (2008), “A Retrospective Look at the U.S. Productivity Resurgence”, Journal of Economic Perspective, Vol. 22, No. 1, pp. 3-24.

Marrano, Giorgio Mauro and Haskel, Jonathan (2006), "How Much Does the UK Invest in Intangible Assets?”, Working Paper, No. 578, Queen Mary University, London.

Marrano, Giorgio Mauro, Haskel, Jonathan and Wallis, Gavin (2007), "What Happened to the Knowledge Economy? ICT, Intangible Investment and Britain's Productivity Record Revisited”, Working Paper, No. 603, Queen Mary University, London.

OECD (2006), ANBERD Database 2005/06, Paris. 
Screen Digest (2005), "World film production/distribution: production hits a plateau after six years of unbroken growth”, Report.

Solow, Robert M. (1987), “We'd Better Watch Out”, New York Times, July 12, 1987, p. 36. 